\title{
BIOCHEMICAL DETERMINANTS OF AGGRESSIVE BEHAVIOUR - PATHO-PHYSIOLOGICAL CONNECTIONS IN ESRDAND DIALYSIS
}

\author{
IRINA NEGOESCU ${ }^{1 \#}$, DAN ALEXANDRU NICULESCU ${ }^{2,3 \#}$, CRISTIANA DAVID $^{4,5 \#}$, ILEANA $^{2}$ \\ PERIDE $^{4,5 * \#}$, ANDREI NICULAE ${ }^{4,5 \#}$, IONEL ALEXANDRU CHECHERIȚĂ ${ }^{4,5 \#}$, CĂTĂLINA \\ POIANĂ $\breve{A H}^{2,3 \#}$
}

${ }^{I}$ PhD Student, "Carol Davila" University of Medicine and Pharmacy Bucharest, 37 Dionisie Lupu Street, 020021, Bucharest, Romania

${ }^{2}$ Department of Hypophysis and Neuroendocrine Pathology, "C. I. Parhon” National Institute of Endocrinology, 34-38 Aviatorilor Boulevard, 011863, Bucharest, Romania

${ }^{3}$ Clinical Department No. 2, "Carol Davila" University of Medicine and Pharmacy Bucharest, 37 Dionisie Lupu Street, 020021, Bucharest, Romania

${ }^{4}$ Department of Nephrology and Dialysis, “Sf. Ioan” Emergency Clinical Hospital, 13 Vitan-Barzesti Road, 042122, Bucharest, Romania

${ }^{5}$ Clinical Department No. 3, "Carol Davila" University of Medicine and Pharmacy Bucharest, 37 Dionisie Lupu Street, 020021, Bucharest, Romania

*corresponding author: ileana_peride@yahoo.com

\#All authors had equal contribution to this manuscript

\begin{abstract}
Violence and aggression are among the most important problems of the contemporary world. Modern humanity vices, like alcohol, drug abuse, daily stress, but also specific therapies within the positive tendency to prolong life in severe chronic diseases seems to contribute to the ascending trend of aggressive behaviour. A topic of debate is the ability of chronic kidney disease and its treatment to induce biochemical and behavioural changes that predispose to impulsivity. The answer can reveal treatment adjustments (chemical, procedural and psychological) that can be made for improving behavioural condition and the quality of life in these patients.
\end{abstract}

\section{Rezumat}

Violența și tendința la agresivitate reprezintă unele dintre cele mai importante probleme cu care se confruntă societatea contemporană. Amploarea în creștere a fenomenului pare a fi determinată nu numai de viciile lumii moderne (abuzul de alcool și droguri, stresul cotidian), ci și de efectele anumitor terapii menite a prelungi durata de viață în afecțiuni severe infirmizante. Un subiect actual de dezbatere este reprezentat de influența bolii cronice de rinichi și a tratamentului prin hemodializă asupra bazelor biochimice ale agresivității. Elucidarea mecanismelor prin care această afecțiune ar putea favoriza (la nivel chimic, procedural sau psihologic) tendințele impulsive ale individului ar permite modificări terapeutice care să amelioreze problemele comportamentale și calitatea vieții pacientului.

Keywords: aggression, biochemical mediators, chronic kidney disease, haemodialysis

\section{Introduction}

Violence and aggression are among the most important problems of the contemporary world, with uprising prevalence and worsening consequences [1]. Not only modern humanity conditions and addictions, like alcohol, drug abuse and increasing daily stress, but also the positive tendency to prolong life in severe chronic diseases seem to contribute to this proven ascending trend of aggressive behaviour [2, 3]. In the recent years, an increasing number of violent manifestations were reported among patients with disabling chronic diseases, namely oncology patients, those with HIV/AIDS and patients on maintenance haemodialysis treatment (associating or not diabetes mellitus) [4-6]. Impulsive and aggressive actions are reported with increased prevalence in chronic dialysis centres [7-10].

This alarming phenomenon induced several complex analyses regarding the factors that induce and influence violence $[11,12]$.A topic of debate is the ability of chronic kidney disease and it's treatment to induce biochemical and behavioural changes that predispose to impulsivity. The answer can reveal us treatment adjustments (chemical, procedural and psychological) that can be made for improving this condition, along with increasing the quality of life of these patients.

\section{Determinants of aggression}

The determinants of the hostile and aggressive behaviour are genetic, endocrine, biochemical and 
FARMACIA, 2018, Vol. 66, 6

social $[2,13]$. As the genetic and social factors are mostly non-biased, to focus on the biochemical and endocrine components of the aggression complex. The cerebral region that integrates neurohumoral circuits is amygdala, its hyperactivity being responsible for upraising aggressive tendencies [14]. Changes in brain function can be induced by several hormones and other substances which modulate cerebral centres activity. End stage renal disease (ESRD) and dialysis as the most common treatment modality of our days for this condition seem to influence neurotransmitters involved in the process.

\section{Biochemical components involved in modulating the impulsive behaviour - specific changes in chronic dialysis patients}

Serotonin (5-Hydroxytryptamine 5-HT) is secreted by specific cells in gastrointestinal tract and serotoninergic neurons of central nervous system, but also in renal proximal tubules, as MJ Sole et al. demonstrated in interesting studies on male Wistar rats in 1986 [15-17]. 5 -HT can be found in circulating platelets and here the uptake, deposit and release resembles the brain serotonin physiology $[16,17]$. Known to modulate the prefrontal activity by stimulating serotonin $5 \mathrm{HT}_{2}$ receptors in orbital frontal and anterior cingulate cortex, serotonin acts as a local neurotransmitter and paracrine modulator of brain circuits $[18,19]$. Low serotonergic activity predisposes to aggression; Murphy et al, 2002 in studies on human healthy volunteers and De Boer, 2009 on laboratory-bred rats and mice revealed that serotonin and/or the precursor tryptophan deficiency can rise suicidal and violence risks [20, 21]. Serotonin release allows the person to manage unpleasant events with calm and inhibits aggressive actions dictated by genetic features [2, 21].

Barisc and Pivac in 2004 demonstrated, in a casecontrol study including dialysis patients with depressive symptoms (with and without anxiety) versus non-renal patients diagnosed with depression, that serotonin content in platelets is lower in all dialysis patients, but significantly higher in dialysis patients with anxiety compared with depressive individuals. Based on previous studies, and confirmed by recent works, they motivated that low serotonin in ESRD patients is due to low concentration of plasma tryptophan and altered 5-HT synthesis, as well as to the impaired peripheral serotonin uptake determined by the influence of haemodialysis procedure upon platelets; the authors concluded that platelet serotonin content should be further assessed as a marker for anxiety in chronic dialysis patients $[22,23]$. A comprehensive review of Hedayati in 2012 showed that anxiety is a feature of depressive patients and serotonin-selective reuptake inhibitors (SSRIs) used in dialysis patients ameliorate the depression-associated impulsivity, but only a few of the class's representatives are well tolerated (fluoxetine with no dose adjustment; paroxetine, with dose adjustment; sertraline may increase the risk of bleeding after dialysis sessions) [24].

Testosterone. While serotonin can counteract the aggressive impulses, testosterone excess exerts an opposite effect: it promotes impulsivity and violent behaviour in animals [25]. Intensively studied, this rule is uncertain in humans. Testosterone level is low in chronic dialysis males and should have protective effects against the aggressive behaviour, but this is not the case in real practice [26]. The explanation came later, with the contribution of the studies performed by Coccaro in 2017 and Mehta et al in 2010, highlighted by the documented review of Montoya in 2012, establishing that testosterone high levels trigger aggression only when they coexist with low plasmatic cortisol [27-29].

Cortisol, produced by the zona fasciculata in the adrenal cortex and released in response to stress and hypoglycaemia, was accordingly named "the stress hormone" [30-32]. In relation to impulsivity, cortisol reduces amygdala-mediated anger processing, in opposition with testosterone actions, promoting fear reactions [33].

There are numerous studies revealing the heterogeneous distribution of cortisol levels in chronic dialysis patients. Chinese studies on large cohorts demonstrated that corticoid activity is negatively associated with the glomerular filtration rates, and positively with serum creatinine, as its levels continuously increase with the progression of chronic kidney disease [34]. Other studies found low cortisol levels in haemodialysis patients, but significantly high levels of cortisol metabolites (tetrahydrocortisol, $5 \alpha$-tetrahydrocortisol and tetrahydrocortisone) with toxic effects; high cortisol levels in end stage renal disease were associated with inflammation and increased mortality risk [35-38]. It is certain that the sustained treatment of any inflammatory trigger, the preservation of a healthy vascular access and a good nutrition status without hypoglycaemic events can contribute to maintain normal cortisol levels in dialysis population and ameliorates cardiovascular risks [39]. Cortisol and cortisol metabolites implications in neurohumoral status of chronic renal patients remain subjects for further investigations.

Catecholamines, dopamine and norepinephrine, act by enhancing the predisposition for other directed aggressions [40]. An increased noradrenergic receptors stimulation (e.g. by the alpha agonist clonidine, widely used for hypertension treatment in dialysis) is correlated with irritability [41]. Beta-blockers seem to be effective in reducing aggressive behaviour in patients with brain lesions [42].

Norepinephrine levels are increased in dialysis patients, especially in anuric patients $[43,44]$. Sympathetic over activity in these patients contributes to the aetiology of hypertension, cardiac arrhythmia and severe cardio- 
FARMACIA, 2018, Vol. 66, 6

vascular events and must be counteracted by betaadrenergic antagonists. Yet, the influence of betablockers on aggressive behaviour in dialysis subjects remains to be assessed. Some authors recommend the use of beta-blockers in episodic anxiety of dialysis patients [45]. Brazilian studies found a negative correlation between the beta-blockers use and the anxiety manifestations in haemodialysis patients; furthermore, pindolol was found as a successful antidepressant enhancer in these patients [46].

Gamma-aminobutyric acid (GABA) is also implicated in the aggression mechanisms [47]. Reduced activity of GABA receptors type $A$ and glutamatergic enhancement are associated with aggressive behaviour $[2,48]$. Uraemia is known to reduce the brain GABA release, uptake and degradation, with a simultaneously increase of glutamate levels. It is suggested by some studies that the use of gabapentin can ameliorate high blood pressure levels and psychotic disorders in uremic patients [47]. Haemodialysis reduces the circulating glutamate excess $[49,50]$, but there are no studies to reveal if prolonged dialysis sessions can reduce impulsivity in ESRD patients.

A recent study in chronic dialysis patients connects low levels of parathyroid hormone (iPTH) with anxiety [51]. In relation to this finding, reductions in active vitamin D levels, a common feature of ESRD patients due to the lack of renal hydroxylation, are linked with increased risks of antisocial and impulsive behaviour [52]. The mechanism involves the influence of cholecalciferol on the expression of tryptophan hydroxylase2 (TPH2), an enzyme responsible for serotonin synthesis [53]. The connection between vitamin D levels and serotonin effects was approached by several studies and it seems to be a subject of serious debate which deserves to be further investigated $[54,55]$. Positive results can open new horizons in the management of dialysis patients, as a more serious therapeutic approach of renal mineral and bone disorder can be proved to ameliorate also depression and anxiety tendencies in this population. Native Vitamin D supplements starting from the early chronic kidney disease stages, active vitamin D or vitamin D receptor activators in late stages, the association of calcimimetics in the presence of hypercalcaemic secondary hyperparathyroidism are possible ways to approach this complex issue [55].

As the above mentioned studies have shown, all the substances involved in modulating the behaviour tendencies suffer important variations in maintenance dialysis patients. These biochemical perturbations overlap with many psychological factors affecting this group of patients [56]. Nevertheless, the exhaustive analysis of all found studies regarding neurotransmitters involved in aggression and the influence of dialysis treatment on their levels are, still, topics of debate. More research is needed for determining the real impact of genetic/biochemical/psychological and social in triggering violent reactions and aggressive behaviour acts.

\section{Conclusions}

There are numerous substances involved in generating aggressive tendencies in humans. Their disturbed levels are linked with brain receptors disruptions determining depression in aggressive behaviour. Endstage renal disease has a major negative impact on patient's physical and psychological status and the dialysis procedure itself is demanding, requiring major lifestyle changes and producing psychological distress. On the other hand, toxins accumulation in chronic renal failure and their heterogeneous excretion by dialysis may cause imbalances in hormones favouring/ inhibiting aggressive behaviour. Focusing on biochemical transformations during chronic kidney disease progression, superposed on the humoral and psychosomatic changes produced by the maintenance haemodialysis treatment, the study of aggressive and violent pattern in chronic dialysis patients can bring a light on this subject.

\section{References}

1. Bartolomeos K, Third Milestones of a Global Campaign for Violence Prevention Report 2007: Scaling Up. Geneva: Switzerland, WHO, 2007; http://apps.who.int.

2. Siever LJ, Neurobiology of aggression and violence. Am J Psychiatry., 2008; 165(4): 429-442.

3. Heinz AJ, Beck A, Meyer-Lindenberg A, Sterzer P, Heinz A, Cognitive and neurobiological mechanisms of alcohol-related aggression. Nat Rev Neurosci., 2011; 12(7): 400-413.

4. Niculae A, David C, Dragomirescu RFI, Peride I, Turcu FL, Petcu LC, Covic A, Checherita IA, Correlation between recombinant human erythropoietin dose and inflammatory status in dialysed patients. Rev Chim Bucharest, 2017; 68(2): 354-357.

5. Manda G, Checherita AI, Comanescu MV, Hinescu ME, Redox signaling in diabetic nephropathy: Hypertrophy versus Death choices in mesangial cells and podocytes. Mediators Inflamm., 2015; 2015: 1-13.

6. Capatina C, Ghinea A, Dumitrascu A, Poiana C, Concurrent onset of type 2 diabetes mellitus and central diabetes insipidus in an adult male. Int $J$ Diabetes Dev Ctries., 2016; 36(4): 393-396.

7. Johnson CC, Moss AH, Clarke SA, Working with noncompliant and abusive dialysis patients: practical strategies based on ethics and the law. Adv Ren Replace Ther., 1996; 3(1): 77-86.

8. Sukolsky A, Patients who try our patience. Am J Kidney Dis., 2004; 44(5): 893-901.

9. Hashmi A, Moss AH, Treating difficult or disruptive dialysis patients: practical strategies based on ethical principles. Nat Clin PractNephrol., 2008; 4(9): 515520.

10. Burns T, Smyth A, Reducing aggression in the haemodialysis unit by improving the dialysis experience for patients. Ren Soc Austral J., 2011; 7: 79-89. 
FARMACIA, 2018, Vol. 66, 6

11. Patrick CJ, Psychophysiological correlates of aggression and violence: an integrative review. Philos Trans $R$ Soc Lond B Biol Sci., 2008; 363(1503): 2543-2555.

12. Lane SD, Kjome KL, Moeller FG, Neuropsychiatry of aggression. Neurol Clin., 2011; 29(1): 49-64.

13. Seroczynski AD, Bergeman CS, Coccaro EF, Etiology of the impulsivity/aggression relationship: genes or environment? Psychiatry Res., 1999; 86(1): 41-57.

14. Matthies S, Rüsch N, Weber M, Lieb K, Philipsen A, Tuescher O, Ebert D, Hennig J, van Elst LT, Small amygdala-high aggression? The role of the amygdala in modulating aggression in healthy subjects. World J Biol Psychiatry., 2012; 13(1): 75-81.

15. Sole MJ, Madapalliattam A, Baines AD, An active pathway for serotonin synthesis by renal proximal tubules. Kidney Int., 1986; 29(3): 689-694

16. Mazák K, Dóczy V, Kökösi J, Noszál B, Proton speciation and microspeciation of serotonin and 5hydroxytryptophan. Chem Biodiver., 2009; 6(4): 578-590.

17. Amit A, Mester L, Klewe B, Furberg S, The crystal structure of serotonin hydrogen oxalate. Acta Chem Scand., 1978; 32a: 267-270.

18. New AS, Trestman RL, Mitropoulou V, Benishay DS, Coccaro E, Silverman J, Siever LJ, Serotonergic function and self-injurious behavior in personality disorder patients. Psychiatry Res., 1997; 69(1): 17-26.

19. Winstanley CA, Theobald DE, Dalley JW, Glennon JC, Robbins TW, 5-HT2A and 5-HT2C receptor antagonists have opposing effects on a measure of impulsivity: interactions with global 5-HT depletion. Psychopharmacology (Berl), 2004; 176(3-4): 376-385.

20. Murphy FC, Smith KA, Cowen PJ, Robbins TW, Sahakian BJ, The effects of tryptophan depletion on cognitive and affective processing in healthy volunteers. Psychopharmacology (Berl), 2002; 163(1): 42-53.

21. De Boer SF, Caramaschi D, Natarajan D, Koolhaas $\mathrm{JM}$, The vicious cycle towards violence: focus on the negative feedback mechanisms of brain serotonin neurotransmission. Front Behav Neurosci., 2009; 3: 1-6.

22. Barisić I, Pivac N, Mück-Seler D, Jakovljević M, Sagud $\mathrm{M}$, Comorbid depression and platelet serotonin in hemodialysis patients. Nephron Clin Pract., 2004; 96(1): c10-c14.

23. Schoorl M, Schoorl M, Bartels PCM, Platelet activation and serotonin release during treatment with haemodialysis. Ned Tijdschr Klin Chem Labgeneesk, 2006; 31: 236238.

24. Hedayati SS, Yalamanchili V, Finkelstein FO, A practical approach to the treatment of depression in patients with chronic kidney disease and end-stage renal disease. Kidney International, 2012; 81(3): 247-255.

25. O'Malley BW, A life-long search for the molecular pathways of steroid hormone action. Mol Endocrinol., 2005; 19(6): 1402-1411.

26. Studer E, Näslund J, Andersson E, Nilsson S, Westberg L, Eriksson E, Serotonin depletion-induced maladaptive aggression requires the presence of androgens. PLOS One., 2015; 10(5): 1-12.

27. Coccaro EF, Beresford B, Minar P, Kaskow J, Geracioti $\mathrm{T}$, CSF testosterone: relationship to aggression, impulsivity, and venturesomeness in adult males with personality disorder. J Psychiatr Res., 2007; 41(6): 488-492.

28. Montoya ER, Terburg D, Bos PA, van Honk J, Testosterone, cortisol, and serotonin as key regulators of social aggression: A review and theoretical perspective. Motiv Emot., 2012; 36(1): 65-73.

29. Mehta PH, Josephs RA, Testosterone and cortisol jointly regulate dominance: evidence for a dualhormone hypothesis. Horm Behav., 2010; 58(5): 898-906.

30. Platje E, Popma A, Vermeiren RR, Doreleijers TA, Meeus WH, van Lier PA, Koot HM, Branje, SJ, Jansen LM, Testosterone and cortisol in relation to aggression in a non-clinical sample of boys and girls. Aggress Behav., 2015; 41(5): 478-487.

31. Hydrocortisone. https://pubchem.ncbi.nlm.nih.gov.

32. Gheorghiu ML, Hortopan D, Dumitrascu A, Caragheorgheopol A, Stefanescu A, Trifanescu R, Niculescu DA, Baciu I, Carsote M, Poiana C, Badiu $\mathrm{C}$, Coculescu M, Age-related endocrine tumors: nonfunctioning adrenal tumors as compared to pituitary adenomas. Acta Endo (Buc), 2009; 5(3): 371-384.

33. Poiană C, Neamţu MC, Avramescu ET, Carşote M, Trifănescu R, Terzea D, Neamţu OM, Ferechide D, Dănciulescu Miulescu R, The poor prognosis factors in G2 neuroendocrine tumor. Rom J Morphol Embryol., 2013; 54(3 Suppl): 717-720.

34. Li X, Xiang X, Hu J, Goswami R, Yang S, Zhang A, Wang Y, Li Q, Bi X, Association Between Serum Cortisol and Chronic Kidney Disease in Patients with Essential Hypertension. Kidney Blood Press Res., 2016; 41:384-391.

35. Palmer BF, Cortisol metabolism in chronic kidney disease. UpToDate. 2018; www.uptodate.com.

36. N'Gankam V, Uehlinger V, Dick B, Frey BM, Frey FJ, Increased cortisol metabolites and reduced activity of $11 \beta$ hydroxysteroid dehydrogenase in patients on hemodialysis. Kidney Int., 2002; 61: 1859-1866.

37. Nechita AM, Pituru S, Radulescu D, Peride I, Negreanu L, Niculae A, Ferechide D, Checherita IA, Sinescu $\mathrm{RD}$, Influence of residual diuresis on cardiac biomarker NTproBNP in chronic hemodialysis patients. Farmacia, 2016; 64(3): 348-357.

38. Niculae A, Jinga M, Ciocâlteu A, Lascăr I, Jinga V, Checheriţă IA, Correlation between albuminemia, natremia and survival rates in patients with hepatorenal syndrome. Rom J Morphol Embryol., 2011; 52(3): 863-866.

39. Checheriță IA, Tuță LA, David C, Peride I, Niculae A, Geavlete BF, Pricop C, Ion DA, An overview of permanent vascular access in hemodialyzed patients. Rom J Morphol Embryol., 2015; 56(1): 27-31.

40. de Almeida RM, Ferrari PF, Parmigiani S, Miczek KA, Escalated aggressive behavior: dopamine, serotonin and GABA. Eur J Pharmacol., 2005; 526(1-3): 51-64.

41. Coccaro EF, Lawrence T, Trestman R, Gabriel S, Klar HM, Siever LJ, Growth hormone responses to intravenous clonidine challenge correlate with behavioral irritability in psychiatric patients and healthy volunteers. Psychiatry Res., 1991; 39(2): 129-139.

42. Fleminger S, Greenwood RJ, Oliver DL, Pharmacological management for agitation and aggression in people 
with acquired brain injury. Cochrane Database Syst Rev., 2006; (4):CD003299.

43. Zbroch E, Koc-Zorawska E, Malyszko J, Malyszko $\mathrm{J}$, Mysliwiec M, Circulating levels of renalase, norepinephrine, and dopamine in dialysis patients. Ren Fail., 2013; 35(5): 673-679.

44. Zbroch E, Musialowska D, Koc-Zorawska E, Malyszko $\mathrm{J}$, Age influence on renalase and catecholamines concentration in hypertensive patients, including maintained dialysis. Clin Interv Aging., 2016; 11: 1545-1550.

45. Cohen SD, Cukor D, Kimmel PL, Anxiety in patients treated with hemodialysis: symptom and diagnosis. Clin J Am Soc Nephrol., 2016; 11: 2250-2255.

46. Stasiak CES, Bazan KS, Kuss RS, Schuinski AFM, Baroni G, Prevalence of anxiety and depression and its comorbidities in patients with chronic kidney disease on hemodialysis and peritoneal dialysis. Braz $J$ Nephrology, 2014; 36(3): 325-331.

47. Chen HH, Cheng PW, Ho WY, Lu PJ, Lai CC, Tseng YM, Fang HC, Sun GC, Hsiao M, Liu CP, Tseng CJ, Renal denervation improves the baroreflex and GABA system in chronic kidney disease-induced hypertension. Scientific Reports, 2016; 6: 1-13.

48. Hrabovszky E, Halász J, Meelis W, Kruk MR, Liposits Z, Haller J, Neurochemical characterization of hypothalamic neurons involved in attack behavior: glutamatergic dominance and co-expression of thyrotropin-releasing hormone in a subset of glutamatergic neurons. Neuroscience, 2005; 133(3): 657-666.

49. Rogachev B, Ohayon S, Saad A, Vorobiovsky V, Gruenbaum BF, Leibowitz A, Boyko M, Shapira Y,
Shnaider A, Zlotnik M, The effects of hemodialysis on blood glutamate levels in chronic renal failure: implementation for neuroprotection. J Crit Care., 2012; 27(6):743.e1-743.e7.

50. Rogachev B, Tsesis S, Gruenbaum BF, Gruenbaum SE, Boyko M, Klein M, Shapira Y, Vorobiev M, Zlotnik A, The effects of peritoneal dialysis on blood glutamate levels: implementation for neuroprotection. J Neurosurg Anesthesiol., 2013; 25(3): 262-266.

51. Najafi A, Keihani S, Bagheri N, Ghanbari Jolfaei A, Mazaheri Meybodi A, Association between anxiety and depression with dialysis adequacy in patients on maintenance hemodialysis. Iranian J Psychiatry Behav Sci., 2016; 10(2): 1-7.

52. Patrick RP, Ames BN, Vitamin D hormone regulates serotonin synthesis. Part 1: relevance for autism. The FASEB Journal, 2014; 28(6): 2398-413.

53. Crockett MJ, The neurochemistry of fairness. Ann NY Acad Sci., 2009; 1167(1): 76-86.

54. Patrick RP, Ames BN. Vitamin D and the omega-3 fatty acids control serotonin synthesis and action, part 2: relevance for ADHD, bipolar disorder, schizophrenia, and impulsive behavior. FASEB J., 2015; 29(6): 2207-2222.

55. KDIGO clinical practice guideline for the diagnosis, evaluation, and treatment of chronic kidney diseasemineral and bone disorder (CKD-MBD). Kidney Int., 2017; 7(Suppl 1): S1-S59.

56. Jones J, Nijman H, Ross J, Ashman N, Callaghan P, Aggression on hemodialysis units: a mixed method study. J Ren Care., 2014; 40(3): 180-193. 